[Letter]

\title{
Formation of Higher Hydrocarbons from Chloromethanes via Hydrodechlorination over $\mathrm{Pd} / \mathrm{SiO}_{2}$ Catalyst
}

\author{
Tohru Mori, Kouichi Hirose, Takashi Kikuchi, Jun Kubo, and Yutaka Morikawa* \\ Chemical Resources Laboratory, Tokyo Institute of Technology, \\ 4259 Nagatsuta-cyo, Midori-ku, Yokohama 226-8503, JAPAN
}

(Received April 30, 2002)

The hydrodechlorination of chloromethanes over $\mathrm{Pd} / \mathrm{SiO}_{2}$ gave higher hydrocarbons selectively. The produced hydrocarbons followed well the Schulz-Flory distribution, indicating that the hydrocarbons were formed via polymerization of surface $C_{1}$ species. The probability of chain-growth was increased in the order of the reactivity of chloromethane, that is, $\mathrm{CH}_{2} \mathrm{Cl}_{2}<\mathrm{CHCl}_{3}<\mathrm{CCl}_{4}$.

\section{Keywords}

Hydrodechlorination, Palladium catalyst, Hydrocarbon, Chloromethane, Schulz-Flory distribution

\section{Introduction}

In recent years, catalytic hydrodechlorination of chlorine-containing compounds has been studied extensively to convert them into environmentally benign and more useful products. It has been known that $\mathrm{C}-\mathrm{C}$ bond formation takes place during the hydrodechlorination of chlrofluorocarbons ${ }^{1-5)}$ and chlorometahnes ${ }^{6-9)}$. van Barneveld and $\mathrm{Ponec}^{6)}$ have studied the hydrodechlorination of $\mathrm{CH}_{2} \mathrm{Cl}_{2}$ and $\mathrm{CHCl}_{3}$ over various metal black catalysts and reported that $\mathrm{Ni}$ and Co catalysts appear to be active for $\mathrm{C}$ $\mathrm{C}$ bond formation to form hydrocarbons having chain length up to $\mathrm{C}_{4}$. They also reported that the chain growth rate was negligible over a Pd black catalyst. However, we found that $\mathrm{Pd} / \mathrm{SiO}_{2}$ catalyzed the $\mathrm{C}-\mathrm{C}$ bond formation selectively to give $\mathrm{C}_{2}-\mathrm{C}_{7}$ hydrocarbons in the hydrodechlorination of $\mathrm{CHCl}_{3}$ and the produced hydrocarbons followed well the Schulz-Flory distribution ${ }^{10)}$. The activities of supported Pd catalysts have been investigated for the hydrodechlorination of other chloromethanes. The hydrodechlorination of $\mathrm{CCl}_{4}$ over $\mathrm{Pd} / \mathrm{C}$ and $\mathrm{Pd}_{2} / \mathrm{TiO}_{2}$ yields hydrocarbons having chain length up to $\mathrm{C}_{5}$ and these catalysts were deactivated rapidly ${ }^{8)}$, whereas that of $\mathrm{CH}_{2} \mathrm{Cl}_{2}$ over $\mathrm{Pd} / \gamma-\mathrm{Al}_{2} \mathrm{O}_{3}$ yields $\mathrm{Cl}-\mathrm{H}$ replacement product, $\mathrm{CH}_{4}$ and $\mathrm{CH}_{3} \mathrm{Cl}$, selectively ${ }^{11)}$. However, comparative studies have not been made on the hydrodechlorination of various chloromethanes over the same Pd catalyst.

In the present research, the hydrodechlorination of chloromethanes over $\mathrm{Pd} / \mathrm{SiO}_{2}$ catalyst was investigated using a pulse reaction system to understand the catalytic chemistry of C-C bond formation in the hydrodechlorination of chloromethanes.

\section{Experimental}

$\mathrm{Pd} / \mathrm{SiO}_{2}$ catalyst was prepared by an ion-exchange method using CARiACT Q-30 (Fuji Silysia Chemical Ltd., $d=70-200 \mu \mathrm{m}$, surface area $=96 \mathrm{~m}^{2} / \mathrm{g}$ ) as a support. The silica support was immersed in an ammoniacal solution of $\mathrm{Pd}\left(\mathrm{NH}_{3}\right)_{4} \mathrm{Cl}_{2}$ at $\mathrm{pH} 11$. The ion-exchange was performed at room temperature

\footnotetext{
“Pd/SiO 2 触媒上での水素化脱塩素を経由するクロロメタン類からの高級炭化水素の生成”

森 亨, 廣瀬 浩一, 菊池 崇, 久保 純, 森川 豊*

東京工業大学資源化学研究所, 226-8503 横浜市緑区長津田町 4259

*連絡先, E-mail: ymorikaw@res.titech.ac.jp
} 
for $24 \mathrm{~h}$. The resulting solid was washed thoroughly with distilled water and dried in an oven overnight at $110^{\circ} \mathrm{C}$. The amount of palladium loading was determined by $\mathrm{X}$-ray fluorescence spectrometer (Shimadzu EDX-800) to be $0.50 \mathrm{wt} \%$.

The reaction of chloromethane, $\mathrm{CH}_{2} \mathrm{Cl}_{2}, \mathrm{CHCl}_{3}$, or $\mathrm{CCl}_{4}$, with hydrogen was carried out in a pulse reaction system with a Pyrex glass reactor $(4 \mathrm{~mm}$ i.d.). Prior to the reaction, the catalyst $(30 \mathrm{mg})$ was reduced in a hydrogen stream at $450^{\circ} \mathrm{C}$ for $2 \mathrm{~h}$. Chloromethanes were pulsed into the reactor by using a micro syringe. The amount of each pulse was $c a .10 \mu \mathrm{mol}$, and the pulse interval was $60 \mathrm{~min}$. The effluent gas was analyzed on-line by a gas chromatograph (Shimadzu GC-14A) equipped with a $4 \mathrm{~m}$ Gaskuropack 54 column (GL Sciences Inc.) and a flame ionization detector. The products were identified with a GC-MS (Hitachi M-80B) using the same column.

\section{Results and Discussion}

The results of hydrodechlorination of chloromethanes over $\mathrm{Pd} / \mathrm{SiO}_{2}$ are shown in Table 1 . The C-C bond formation to give $\mathrm{C}_{2}-\mathrm{C}_{7}$ hydrocarbons took place during the hydrodechlorination of $\mathrm{CHCl}_{3}$ over $\mathrm{Pd} / \mathrm{SiO}_{2}$. The total selectivity of $\mathrm{C}_{2}-\mathrm{C}_{7}$ hydrocarbons was $37 \%$ at $175^{\circ} \mathrm{C}$ and the $\mathrm{Cl}-\mathrm{H}$ replacement product, $\mathrm{CH}_{2} \mathrm{Cl}_{2}$, was formed at the selectivity as low as $0.6 \%$. The hydrocarbons produced were alkanes and the ratios of branched to normal were $0.17,0.76$, and 1.0, for $\mathrm{C}_{4}, \mathrm{C}_{5}$, and $\mathrm{C}_{6}$, respectively. These results agreed well with those obtained with conventional flow-type reaction system ${ }^{10)} \cdot \mathrm{CH}_{2} \mathrm{Cl}_{2}$ was most inactive among chloromethanes tested here, giving the low conversion of $37 \%$ even at high temperature of $250^{\circ} \mathrm{C}$ and the $\mathrm{Cl}-\mathrm{H}$ replacement product, $\mathrm{CH}_{3} \mathrm{Cl}$, was yielded at relatively high selectivity $(>5 \%)$. The hydrocarbons produced in the reaction were also alkanes, but $\mathrm{C}_{5_{+}}$alkanes were not produced. Malinowski et al. ${ }^{11)}$ have studied the hydrodechlorination of $\mathrm{CH}_{2} \mathrm{Cl}_{2}$ over $\mathrm{Pd} / \gamma-\mathrm{Al}_{2} \mathrm{O}_{3}$ and reported that the selectivity to $\mathrm{CH}_{4}, \mathrm{CH}_{3} \mathrm{Cl}$ and $\mathrm{C}_{2} \mathrm{H}_{6}$ at $140^{\circ} \mathrm{C}$ was $69 \%, 31 \%$ and less than $1 \%$,

Table 1 Hydrodechlorination of Chloromethanes over $\mathrm{Pd} / \mathrm{SiO}_{2}$ Catalyst

\begin{tabular}{|c|c|c|c|c|c|c|}
\hline \multirow{2}{*}{$\begin{array}{l}\text { Reactant } \\
\text { Reaction temp. }\left[{ }^{\circ} \mathrm{C}\right]\end{array}$} & \multicolumn{2}{|c|}{$\mathrm{CCl}_{4}$} & \multicolumn{2}{|c|}{$\mathrm{CHCl}_{3}$} & \multicolumn{2}{|c|}{$\mathrm{CH}_{2} \mathrm{Cl}_{2}$} \\
\hline & 125 & 175 & 125 & 175 & 250 & 300 \\
\hline Conversion [\%] & 24.8 & 81.9 & 21.6 & 79.8 & 37.0 & 80.2 \\
\hline \multicolumn{7}{|l|}{ Selectivity [\%] } \\
\hline $\mathrm{CH}_{4}$ & 3.4 & 4.6 & 89.9 & 62.1 & 89.6 & 86.7 \\
\hline $\mathrm{C}_{2} \mathrm{H}_{4}$ & 0.35 & 2.1 & 0 & 0 & 0 & 0 \\
\hline $\mathrm{C}_{2} \mathrm{H}_{6}$ & 4.0 & 11.0 & 7.5 & 24.8 & 0.90 & 7.2 \\
\hline $\mathrm{C}_{3} \mathrm{H}_{6}$ & 0.18 & 3.1 & 0 & 0 & 0 & 0 \\
\hline $\mathrm{C}_{3} \mathrm{H}_{8}$ & 2.3 & 4.6 & 2.2 & 7.6 & 0 & 0.43 \\
\hline$\Sigma \mathrm{C}_{4}{ }^{\mathrm{a})}$ & 2.0 & 4.5 & 0.4 & 3.3 & 0 & 0.04 \\
\hline$\Sigma \mathrm{C}_{5}{ }^{\mathrm{a})}$ & 1.4 & 3.1 & 0.09 & 1.2 & 0 & 0 \\
\hline$\Sigma \mathrm{C}_{6}{ }^{\mathrm{a})}$ & 0.85 & 2.5 & 0 & 0.46 & 0 & 0 \\
\hline$\Sigma \mathrm{C}_{7}^{\mathrm{a})}$ & 0.44 & 1.5 & 0 & 0.10 & 0 & 0 \\
\hline$\sum \mathrm{C}_{2-7}{ }^{\mathrm{b}}$ & 11.5 & 32.2 & 10.2 & 37.5 & 0.90 & 7.7 \\
\hline $\mathrm{CH}_{3} \mathrm{Cl}$ & 0 & 0 & 0 & 0 & 9.5 & 5.7 \\
\hline $\mathrm{CH}_{2} \mathrm{Cl}_{2}$ & 0.03 & 0.17 & tr. & 0.54 & - & - \\
\hline $\mathrm{CHCl}_{3}$ & 0.04 & 1.9 & - & - & 0 & 0 \\
\hline $\mathrm{C}_{2} \mathrm{H}_{\mathrm{x}} \mathrm{Cl}_{4-\mathrm{x}}$ & 0.92 & 5.2 & 0 & 0 & 0 & 0 \\
\hline Total $^{c}$ & 16.0 & 44.1 & $>99.9$ & $>99.9$ & $>99.9$ & $>99.9$ \\
\hline
\end{tabular}

a) The sum of alkanes and alkenes selectivity. b) Total selectivity of $C_{2}-C_{7}$ hydrocarbons.

c) Total selectivity of gaseous products. 
respectively. The difference in the product distribution from present result seems to be attributed to the different reaction condition, particularly reaction temperature. The reactivity of $\mathrm{CCl}_{4}$ was slightly higher than that of $\mathrm{CHCl}_{3}$. Every value of the selectivity to $\mathrm{C}_{4+}$ hydrocarbon was higher than that observed for the reaction of $\mathrm{CHCl}_{3} . \mathrm{C}_{2+}$ alkenes and chlorinated ethane, $\mathrm{C}_{2} \mathrm{HCl}_{3}$ and $\mathrm{C}_{2} \mathrm{Cl}_{4}$, were also formed, implying insufficiency of adsorbed hydrogen on Pd surface. The total selectivity of gaseous products obtained in the reaction of $\mathrm{CCl}_{4}$ was lower than those obtained in the reactions of $\mathrm{CH}_{2} \mathrm{Cl}_{2}$ and $\mathrm{CHCl}_{3}$. The fact suggests the formation of hydrocarbons having chain-length longer than $\mathrm{C}_{8}$ and carbonaceous deposit.

The reactivity of chloromethanes increases in the order of $\mathrm{CH}_{2} \mathrm{Cl}_{2}<\mathrm{CHCl}_{3}<\mathrm{CCl}_{4}$, that is, the reactivity of chloromethanes increases with increasing the number of chlorine atoms in them. The result agrees with the order of reactivity for the reaction over $\mathrm{Pt} / \mathrm{Al}_{2} \mathrm{O}_{3}$ catalysts to form $\mathrm{Cl}-\mathrm{H}$ replacement products ${ }^{9), 12)}$. The reactivity of chloromethanes can be explained by their carbon-chlorine bond energies. The dissociation energy of carbon-chlorine bond was $59.6,66.2$, and $70.3 \mathrm{kcal} \mathrm{mol}^{-1}$ in $\mathrm{CCl}_{4}$, $\mathrm{CHCl}_{3}$, and $\mathrm{CH}_{2} \mathrm{Cl}_{2}$, respectively ${ }^{13)}$. The conversions of $\mathrm{CCl}_{4}$ are not so high as expected from its low C$\mathrm{Cl}$ bond energy. This might be caused by the higher coverage of adsorbed chlorine, which results from the dissociative adsorption of $\mathrm{CCl}_{4}$ because of its lower $\mathrm{C}-\mathrm{Cl}$ bond energy and prevents the adsorption of hydrogen and $\mathrm{CCl}_{4}$ itself.

Figure 1 shows the Schulz-Flory plots for the composition of hydrocarbons formed in the hydrodechlorination of chloromethanes over $\mathrm{Pd} / \mathrm{SiO}_{2}$. The product distributions obtained with three chloromethanes were well described by the Schulz-Flory distribution. The correlation coefficient was 0.998 for $\mathrm{CH}_{2} \mathrm{Cl}_{2}, 0.996$ for $\mathrm{CHCl}_{3}$, and 0.950 for $\mathrm{CCl}_{4}$. These results indicate that higher hydrocarbons are formed through the polymerization of surface $C_{1}$ species like a Fischer-Tropsch reaction. Although the surface $\mathrm{C}_{1}$ species is not well understood yet at this stage of investigation, the $\mathrm{C}_{1}$ species is considered to be methylene group $\left(=\mathrm{CH}_{\mathrm{x}} \mathrm{Cl}_{2-\mathrm{x}}\right)$ formed by dechlorination/hydrogenation of adsorbed chloromethanes. It is generally agreed that the $C_{1}$ species in the Fischer-Tropsch reaction is the surface

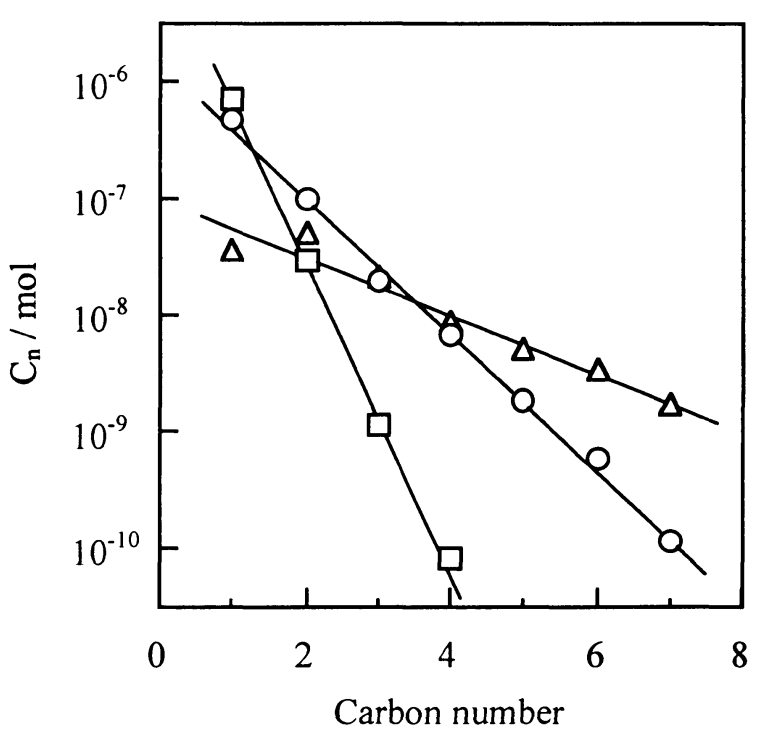

Fig. 1 Schulz-Flory Plots for Hydrocarbons Formed in the Hydrodechlorination of $\mathrm{CH}_{2} \mathrm{Cl}_{2}$ at $300^{\circ} \mathrm{C}(\square), \mathrm{CHCl}_{3}$ $(\bigcirc)$ and $\mathrm{CCl}_{4}(\triangle)$ at $175^{\circ} \mathrm{C}$ methylene $\left(=\mathrm{CH}_{2}\right)$ formed by the hydrogenation of dissociated $\mathrm{CO}^{14)}$.

The probability of chain-growth was calculated from the slope of each line in Fig. 1, to be 0.048 for $\mathrm{CH}_{2} \mathrm{Cl}_{2}, 0.26$ for $\mathrm{CHCl}_{3}$, and 0.56 for $\mathrm{CCl}_{4}$, which increased with increasing the reactivity of chloromethanes. This result is explainable by the surface concentration of $\mathrm{C}_{1}$ species and hydrogen adsorbed on Pd. The probability of chain-growth $(\alpha)$ is expressed by Eq. (1), considering the rates of propagation and termination in the polymerization of surface methylene; where $\left[A_{n}\right]$ is the concentration of surface alkene species having $\mathrm{n}$ carbon atoms, $k_{p}$ and $k_{t}$ are the rate constants of the propagation and termination steps, respectively, $\left[\mathrm{C}_{1}\right]$ and $[\mathrm{H}]$ are the concentrations of surface methylene and adsorbed 
hydrogen, respectively ${ }^{15)}$.

$$
\alpha=\frac{\left[\mathrm{A}_{\mathrm{n}}\right]}{\left[\mathrm{A}_{\mathrm{n}-1}\right]}=\frac{k_{p}\left[\mathrm{C}_{1}\right]}{k_{p}\left[\mathrm{C}_{1}\right]+k_{1}[\mathrm{H}]}
$$

The lower reactivity of $\mathrm{CH}_{2} \mathrm{Cl}_{2}$ seems to cause the lower concentration of surface methylene, leading to the higher concentration of adsorbed hydrogen $\left(k_{p}\left[\mathrm{C}_{1}\right] \ll k_{t}[\mathrm{H}]\right)$, and hence the probability of chaingrowth shows the lower value in the reaction of $\mathrm{CH}_{2} \mathrm{Cl}_{2}$. On the other hand, $\mathrm{CCl}_{4}$ might adsorb dissociatively at a high coverage on Pd surface because of its lower $\mathrm{C}-\mathrm{Cl}$ bond energy, resulting in the higher concentration of surface methylene and the lower concentration of adsorbed hydrogen $\left(k_{p}\left[\mathrm{C}_{1}\right] \geq\right.$ $\left.k_{t}[\mathrm{H}]\right)$. The shortage of adsorbed hydrogen must give the higher probability in the chain-growth and the formation of alkenes as shown in Table 1.

\section{References}

1) Ueda, W., Tomioka, S., Okada, M., Saito, A., Sakamoto, T., Ikawa, T., Morikawa, Y., Shokubai, 33, 95 (1991).

2) Tomioka, S., Mori, T., Ueda, W., Morikawa, Y., Ikawa, T., Chem. Lett., 1991, 1825.

3) Mori, T., Ueda, W., Morikawa, Y., Catal. Lett., 38, 73 (1996).

4) Wiersma, A., van de Sandlt, E. J. A. X., den Hollander, M. A., van Bekkum, H., Makke, M., Moulijn, J. A., J. Catal., 177, 29 (1998).

5) Kulkarni, P. P., Deshmukh, S. S., Kovalchuk, V. I., d'Itri, J. L., Catal. Lett., 61, 161 (1999).

6) van Barneveld, W. A. A., Ponec, V., J. Catal., 88, 382 (1984).

7) Weiss, A. H., Valinski, S., Antoshin, G. V., J. Catal., 74, 136 (1982).

8) Lokteva, E. S., Lunin, V. V., Golubina, E. V., Simagina, V. I., Egorova, M., Stoyanova, I. V., in "Proceedings of the 12th International Congress on Catalysis, Granada, 2000," eds. by Corma, A., Melo, F. V., Mendioroz, S., Fierro, J. L. G., Elsevier, Amsterdam (2000), Part C, p. 1997.

9) Bae, J. W., Park, E. D., Lee, J. S., Lee, K. H., Lee, K. H., Kim, Y. G., Yeon, S. H., Sung, B. H., Appl. Catal., A, 217, 79 (2001).

10) Mori, T., Kikuchi T., Kubo, J., Morikawa, Y., Chem. Lett., 2001, 936.

11) Malinowski, A., Lomot, D., Karpinski, Z., Appl. Catal., B, 19, L79 (1998).

12) Weiss, A. H., Gambhir B. S., Leon, R. B., J. Catal., 22, 245 (1971).

13) Wiberg, K. B., Rablen, P. R., J. Am. Chem. Soc., 115, 614 (1993).

14) Kaminsky, M. P., Winograd, N., Geoffroy, G. L., Vannice, M. A, J. Am. Chem. Soc., 108, 1315 (1986).

15) Long, H. C., Turner, M. L., Fornasiero, P., Kaspar, J., Graziani, M., Maitlis, M., J. Catal., 167, 172 (1997). 